病理組織学的進展像からみた小型肝細胞癌に対する治療方針の選択

\begin{tabular}{|c|c|c|c|c|c|c|c|c|c|c|}
\hline & & & 医 & 科大 & 学第 & 1 夕夕 & & & & \\
\hline 森 & 誠 & 治 & 前 & 場 & 隆 & 志 & 石 & 村 & & 健 \\
\hline 野 & 圭 & 一 & 唐 & 澤 & 幸 & 彦 & 合 & 田 & 文 & \\
\hline 林 & 久 & 男 & 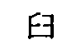 & 杵 & 尚 & 志 & 前 & 田 & & \\
\hline
\end{tabular}

最大腫瘍径 $3 \mathrm{~cm}$ 以下, 3 病巣以下の肝細胞癌 $(\mathrm{HCC})$ 切除 49 例, 56 結節を対象に, 腫 瘍および腫瘍周囲の病理組織像を腫瘍径別（径15mm 以下：12結節，16-20 $\mathrm{mm} ； 20$ 結 節, 21-25mm；16結節，26-30：8 結節)に検討し，選択すべき治療法を考察した. 腫 瘍径 $15 \mathrm{~mm}$ 以下の HCC では，腫瘍周囲進展像（被膜外浸潤・脈管侵襲・肝内転移）陽性 が 1 結節（8.3\%）のみであったため, 経皮的エタノール注入療法（PEIT）が第一選択 と考えられた。しかし，中・低分化型が 6 結節（50\%）に混在していたこと，被膜形成 陰性が 5 結節 (41.7\%) にみられたことは，PEIT 後の局所再発への risk factor として 留意すべきと思われた。腫湟径 $16 \mathrm{~mm}$ 以上の HCCでは被膜浸潤が $59.1 \%$, 腫場から 1 $\mathrm{cm}$ 以内の腫瘍周囲進展像が $45.5 \%$ と高率にみられ, またPEIT 施行後肝切除例の 4 結 節中の 1 例 (腫慯径 $22 \mathrm{~mm}$ ) に肝内転移の組織学的遺残がみられたことから, 腫瘍周囲を 含めた確実な局所コントロールが可能な治療法, すなわち肝切除術やマイクロ波凝固壊 死療法が第一選択となると考えられた。

卖引用語：小型肝細胞癌 $(\mathrm{sHCC}), \mathrm{sHCC}$ の病理学的進展像, sHCC に対する治療方針

\section{緒 言}

近年の画像診断の進歩とともに小型肝細胞癌 (sHCC) を治療する機会が増加している ${ }^{122)}$. sHCCに 対する治療法は肝切除以外に, 経皮的エタノール注入 療法 (PEIT), 経皮的マイク口波凝固壊死療法 (PMCT)，また最近では Radio-frequency ablation

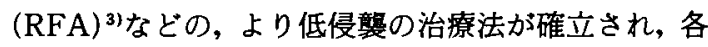
施設により治療の選択に差がみられるのが現況と思わ れる.

sHCC では多中心性発生を念頭に入れた初期治療の 選択が論議されているが，いずれの治療法であっても 確実な局所コントロールが必須である. PEITに関し ては sHCC に対する治療後の生存率が良好との報告“) がある一方, PEIT 後の切除標本上で腫瘍被膜内ある いは被膜外浸潤部に癌紐胞遗残を認めたとの報告5)6 など，PEIT の局所効果の普遍性を嶷問視する意見も

2000 年 2 月 3 日受付 2001 年 7 月 10 日採用 〈所属施設住所〉

テ761-0793 香川県木田郡三木町池戸1750- 1
少なくない.そこで sHCC に対する至適な治療法の選 択のため, 腫瘍径 $3 \mathrm{~cm}$ 以下, 3 病单以下肝細胞癌 (HCC) 切除例を対象に, 腫瘍および腫瘍周囲の病理 組織学的進展像を検討した。

\section{対象と方法}

1985年 4 月から1999年10月までの HCC 切除例のう ち最大腫場径 $3 \mathrm{~cm}$ 以下, 3 結節以下の 49 例, 56 結節を 対象とした（49例中亜区域以下，区域以上切除例はそ れぞれ33，16例)。最大腫湯径別に A 群 $(\mathrm{n}=12): 15$ $\mathrm{mm}$ 以下, B 群 $(\mathrm{n}=20): 16 \sim 20 \mathrm{~mm}, \mathrm{C}$ 群 $(\mathrm{n}=16)$ : $21 \sim 25 \mathrm{~mm}, \mathrm{D}$ 群 $(\mathrm{n}=8): 26 \sim 30 \mathrm{~mm}$ の 4 群に分類し た. 切除肝㵴の $3 \sim 5 \mathrm{~mm}$ 間隔連続階段状切片の Hematoxylin-Eosin 染色 (H-E) 標本を用い, 腫瘍部 の組織分化度 (高分化型のみと中, 低分化型を伴う 2 群に分類), 被膜 (fc), 被膜浸潤（fc-inf）の有無と被 膜厚, 癌の被膜哚達度 (被膜浸潤距離 $\div$ 被膜厚), 腫瘍 周囲進展像（被膜外浸潤・脈管侵奬 (vp) - 肝内転移 (im)）の有無とそれぞれの腫瘍辺縁からの距離を測 定し 4 群間で比較検討した.さらに組織分化度と fcinf ・腫湯周囲進展像の関係を検討した。また当院内科 
表 1 腫瘦の病理組織像

\begin{tabular}{|c|c|c|c|c|c|}
\hline 群 & $\begin{array}{c}\text { 高分化型のみの } \\
\text { 肝細胞䍄(\%) }\end{array}$ & $\begin{array}{l}\text { 被膜形成 } \\
\text { 陽性 }(\%)\end{array}$ & $\begin{array}{l}\text { 被膜厚 } \\
(\mathrm{mm})\end{array}$ & $\begin{array}{c}\text { 被膜内浸潤 } \\
\text { 陽性 }(\%)\end{array}$ & 被膜深達度 $^{\S}$ \\
\hline$A(n=12)$ & $50.0^{*}$ & 58.3 & $0.57 \pm 0.22$ & $33.3^{* *}$ & $0.72 \pm 0.10$ \\
\hline$B(n=20)$ & 20.0 & 60.0 & $1.01 \pm 0.43$ & 45.0 & $0.69 \pm 0.23$ \\
\hline$C(n=16)$ & 5.9 & 64.7 & $1.02 \pm 0.31$ & 62.5 & $0.66 \pm 0.14$ \\
\hline$D(n=8)$ & $0-$ & 87.5 & $1.06 \pm 0.52$ & $87.5-$ & $0.76 \pm 0.21$ \\
\hline \multicolumn{6}{|c|}{$\begin{array}{l}\S: \text { 被膜内浸潤距離 } \div \text { 被膜厚 } \\
*: p=0.0019\end{array}$} \\
\hline
\end{tabular}

表 2 腫湯周囲進展像

\begin{tabular}{|c|c|c|c|c|}
\hline 群 & $\begin{array}{l}\text { 被膜外浸潤 } \\
\text { 陽性 }\end{array}$ & $\mathrm{vp}(+)^{\#}$ & $\operatorname{im}(+)^{\# \#}$ & $\begin{array}{l}3 \text { 因子中 } 1 \text { 因子 } \\
\text { 以上が陽性 }\end{array}$ \\
\hline$A(n=12)$ & 8.3 * & 8.3 & $8.3 * *$ & $8.3 * * *$ \\
\hline$B(n=20)$ & 20.0 & 25.0 & 15.0 & 45.0 \\
\hline$C(n=16)$ & 31.3 & 25.0 & 18.7 & 31.3 \\
\hline$D(n=8)$ & $62.5]$ & 37.5 & $50.0-$ & $75.0-$ \\
\hline
\end{tabular}

単位: \%

*: $\mathrm{p}=0.0097 \quad * *: \mathrm{p}=0.0478 \quad * * *: \mathrm{p}=0.0238$

\#：腫喤周囲での脈管浸潤陽性

\#\#：睡演周囲での肝内転移陽性

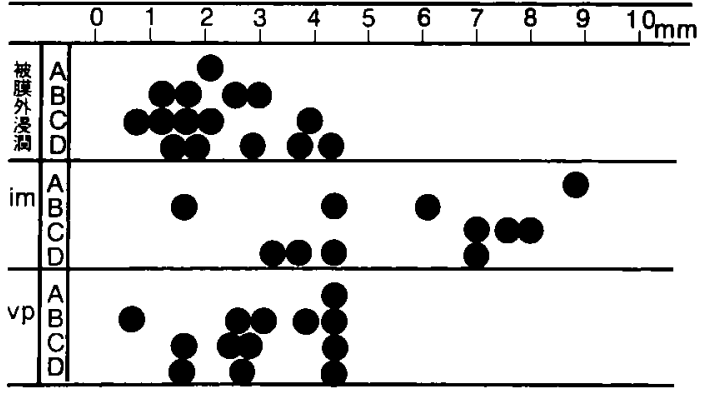

図 1 腫瘍周囲進展因子と腫瘍被膜からの距離

でエコーガイド下に PEIT が施行された 4 結節（単発 HCC で腫瘍径 $14 \mathrm{~mm}, 14 \mathrm{~mm}, 22 \mathrm{~mm}, 30 \mathrm{~mm}$ に対し, エタノール 4〜8 ml/回, 3〜 4 回注入) の肝切除例 (それぞれ PEIT 後 $8,2 ， 10,3$ 力月) の腫瘍およ び腫瘍周囲部の病理組織像を観察した。

な抢統計学的数值は mean $\pm \mathrm{SD}$ で示し, 有意差検定 は $\chi^{2}$ 検定, Bartlett, One-factor ANOVA, Spearman rank correlation 検定を用い, $\mathrm{p}<0.05$ を有意差ありと 判定した.

結果

\section{1. 腫瘍の病理組織像（表 1 ）}

腫湯径の増大とともに高分化型のみで構成される
HCC では有意に減少した $(\mathrm{p}=0.0019) \cdot \mathrm{A}$ 群中でも50 \%の症例に中, 低分化型の混在を認めた. fc は A 群で も約 $58 \%$ に認め, 腫慯径との相関はなく,また fc 厚も 4 群間に有意差を認めなかった。 fc-inf は隀瘍径の増 大とともに陽性例が有意に増加した $(\mathrm{p}=0.0123)$ が, 被膜深達度には有意差を認めなかった。

\section{2. 腫瘍周囲の病理組織学的進展像}

腫場径の増大とともに被膜外浸潤陽性, im 陽性ある いは被膜外浸潤・im・vp の 3 因子のうち 1 因子以上が 陽性の HCC が有意に増加した（それぞれ $\mathrm{p}=0.0097$, $0.0478,0.0238$ ) (表 2 ). A 群にも 3 因子すべてを伴っ た 1 例 (8.3\%)を認めた。この症例は腫湯径 $15 \mathrm{~mm} て ゙$, fc-inf も陽性, 腫場最大割面の 8 割が中分化型で構成 されていた。

また被膜外浸潤・vp・im はいずれも腫瘍辺縁より 10 $\mathrm{mm}$ 以内に存在した（図 1 )。

中, 低分化型を伴う HCC は高分化型のみの HCC に 比し被膜内浸潤, 腫場周囲進展像とも有意に陽性例が 増加した（それそれ $\mathrm{p}=0.0271 ， 0.0299$ （表 3 ).

\section{PEIT 施行後肝切除例の病理組織像}

PEIT 施行後に肝切除が施行された 4 結節では主腫 瘍部の完全壊死は認められたが, PEIT 前腫湯径22 $\mathrm{mm}$ の 1 例で主腫湯より $3 \mathrm{~mm}$ 離れた部位に中分化型 
表 3 腫瘍内の組織分化型構成と被膜内浸潤・腫瘍周囲 進展像

\begin{tabular}{l|c|c}
\hline & 被膜内浸潤陽性 & 腫湯周囲進展陽性\# \\
\hline 高分化型 $(\mathrm{n}=11)$ & 18.2 \\
中・低分化型 $(\mathrm{n}=45)$ & 62.2 & 9.1 \\
\hline
\end{tabular}

単位:\%

$*: \mathrm{p}=0.0271 \quad * *: \mathrm{p}=0.0299$

\#：被膜外浸潤・ vp $\cdot \mathrm{im} の 1$ 因子以上が陽性

の $\operatorname{im}$ の残存を認めた (図 $2 \mathrm{~A}, \mathbf{B})$.

\section{考察}

HCC のうち肝内転移の可能性が少ないと考えられ る $\mathrm{sHCC}$ の治療原則は確実な局所コントロールであ る. PEIT は一般的に腫瘍最大径 $3 \mathrm{~cm}$ 以下, 3 病巣以 内が適応とされており7), 低侵襲, 低コス卜を考慮すれ ば，肝切除に匹敵あるいはより有効であると報告され てきた ${ }^{8) ~ 111}$.一方, PEIT の問題点として癌細胞の穿刺 経路への播種性転移の可能性が報告 ${ }^{12113) さ れ て い る ほ ~}$ か, PEIT 施行後に被膜内あるいは被膜外浸潤部で癌

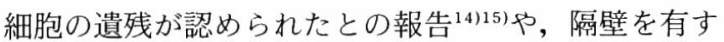
る SHCC の PEIT 後の治療部再発が隔壁を有しない sHCC より多いことから隔壁内の癌遺残が疑われたと

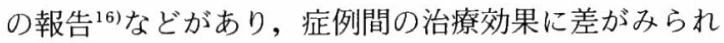
ることを否定できない。またエ夕ノールの代わりに酢 酸を注入するPAIT がPEIT に比しより有効である との報告 ${ }^{17)}$ があり, ラットの実験でもその凝固壊死効 果が証明されている ${ }^{18)}$ が，今だ一般的な治療法とはな っていない.

HCC の病理組織学的進展像を腫瑒径からみると,関 ら $\left.{ }^{19}\right)$ は腫瘍径 $15 \mathrm{~mm}$ 以上 $20 \mathrm{~mm}$ 以下 25 例中, fc-inf を 14 例 $(56 \%)$ ，脈管浸潤を 10 例 $(40 \%)$ ，肝内転移巣を 8 例 (32\%) に認めたと報告し, 山中ら ${ }^{20}$ は, 多結節型 を除いた腫瘍径 $2 \mathrm{~cm}$ 以下の HCC29例中16例（55\%） に脈管侵襲を認めたと報告している. 自験例の腫瘍最 大径 $30 \mathrm{~mm}$ 以下の HCC においても fc-inf が全体の $53.6 \%$, 腫瘍周囲の進展像, すなわ被膜外浸潤・vp・ $\operatorname{im}$ が全体の $37.5 \%$ にられ，ことに $16 \mathrm{~mm}$ 以上では $45.5 \%$ と高率に浸潤像が認められた。また腫場径 22 $\mathrm{mm}$ の PEIT 後肝切除例に腫瘍近傍の im の残存が認 められた。すなわち, 既存の腫瘍径 $30 \mathrm{~mm}$ 以下の適応 基準で PEIT を施行した場合, 腫場周囲部に癌細胞が 残存する可能性は少なくないと考えられる.PEITに よる壊死は被膜外にまで効果を認め, fc-inf や被膜外
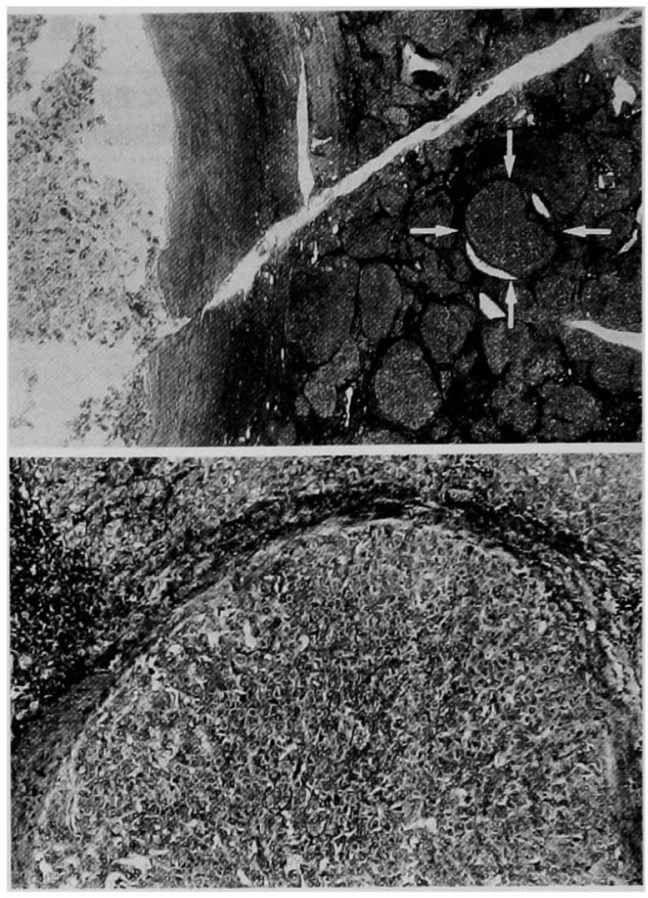

図2 $\mathrm{A}$ ：腫湯部は完全壊死に陥っているものの, 腫瘍辺縁部に im の残存を認めた (白矢印) (HE 染 色, $\times 40)$.

B : im の強拡像で, viable な中分化型 HCC を認めた（HE 染色, $\times 100)$. $\frac{\mathrm{A}}{\mathrm{B}}$

浸潤, 病変近傍の vpにも有効であるとの報告もある が10)，顕鏡レベルの進展像を画像で診断することは困 難な上, エタノールを注入した直後には治療部は高工 コーレベルとなり，その効果の範囲に関する判定は必 ずしも容易ではないことなどから，PEITにより確実 かつ普遍的な治療効果が得られるとは考えにくい.し たがって自験例から判断すると, fc-inf や腫瘍周囲進 展像の可能性が比較的少ない径 $15 \mathrm{~mm}$ 以下（それぞれ $33.3 \% ， 8.3 \%$ ） HCC に対してのみ PEIT が第一選 択になり得ると考えている。しかしながら腫瘍径 15 $\mathrm{mm}$ 以下の HCC に扔いても, 以下の 2 点が PEIT の 問題点となる.第 1 点は $\mathrm{fc}(-)$ 例に対する PEIT の効 果についてであり，自験例の $41.7 \%$ にc $(-)$ 例が存在 した。 fc(一)では実際の手技上エタノール注入直後よ り腫瘍内に停滞することなく脈管内に流出する例がし ばしば観察される，fc(一)の HCC に対する PEIT の 有効性について言及した報告もないことから, 径 15 $\mathrm{mm}$ 以下 HCC といえども fc(一)例では一定した壊死 効果が得られるか否か疑問が残る. 第 2 点は $15 \mathrm{~mm}$ 以 
下でも50\%に中, 低分化型が出現していたことである. 多変量解析によると腫瘍径 $3 \mathrm{~cm}$ 以下 HCCで, PEIT 後の治療部再発に関与する因子は分化度であり, 高分 化型に対し PEIT は有効であったが中, 低分化型では 不良であったとの報告 ${ }^{21}$ や, 腫瘍径 $2 \mathrm{~cm}$ 以下の $\mathrm{HCC}$ での PEIT と PMCT の治療後の予後の比較検討で, 中・低分化型の症例では 5 年生存率, 治療部再発率と

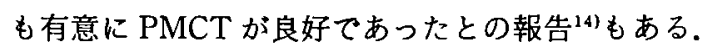
今回の検討でも高分化型に比し中・低分化型を含む HCC では被膜内浸潤像や, 腫暘周囲進展像が有意に高 率で, 中分化型を含む腫崵径 $15 \mathrm{~mm}$ 例で fc-inf, 被膜外 浸潤, vp, im のすべてを伴った 1 例が存在したことか らも，針生検等で中・低分化型を含むことが強く疑わ れる15mm 以下 HCCでは PEIT 施行後も治療部再発 の可能性を考慮した厳重な経過観察が必要であり,む しろ MCT を選択すべきとも思われる．

前述のごとく $30 \mathrm{~mm}$ 以下 HCCでも径 $16 \mathrm{~mm}$ 以上に なると自験例の $45.5 \%$ に腫黇周囲進展像を伴い, その 進展範囲は全例 $1 \mathrm{~cm}$ 以内に存在したことから, 腫瘍 周囲 $1 \mathrm{~cm}$ 以上を含めた確実な局所コントロールが可 能な治療法が要求される。この意味では MCTは腫煌 径 $3 \mathrm{~cm}$ 以下の症例に適応できる可能性が示唆され る.しかし MCT は主グリソン, 肝静脈から $1 \mathrm{~cm}$ 以上 離れた HCCでないと腫場周囲浸潤部を含めた確実な 治療が困難と考えられることや，PMCTでは経皮的 US で死角が存在することから, 適応となる症例はお のずと限定される．最近では人工胸水法により経皮的 US の死角を克服する手法22)なども試みられている が, MCT はいまだ多数例の長期予後の検討がなされ ていないのが現況であり, MCT と肝切除の $\mathrm{SHCC} に$ 対する治療効果の比較は今後の prospective study に よる検討が必要と考えられる.したがって, 現時点で は腫瘍最大径 $16 \mathrm{~mm}$ 以上の HCCに対しては肝切除を 第一選択とし, 肝機能上肝切除困難例, 手術拒否例に 対して PMCT を施行すべきと考えている.

\section{結語}

sHCC の病理組織学的進展像からみて, 腫瘍径 15 $\mathrm{mm}$ 以下の HCC に対してはPEIT を第一選択とし, $16 \mathrm{~mm}$ 以上の HCC には肝切除あるいは MCT を選択 すへきであると考えられた。

\section{文献}

1) Neil D, Schwartz TM, Miller C, et al : Macroregenerative nodules and hepatocellular carcinoma in forty-four sequential adult liver explants with cirrhosis. Hepatology $16: 949-$ 955, 1992

2) 首藤太一, 木下博明, 広橋一裕他: 肝癌切除標本 ではじめて検出された結節性病変の検討。肝缄 $33: 932-937,1992$

3) Livraghi $T$, Goldberg $\mathrm{SN}$, Lazzaroni $\mathrm{S}$, et al : Small hepatocellular carcinoma: Treatment with radio-frequency ablation versus ethanol injection. Radiology $210: 655-661,1999$

4) 椎名秀一朗, 丹波泰郎：肝細胞癌に対する経皮的 エタノール注入療法.日消病会誌 $91: 821-828$, 1994

5) Seki $T$, Nonaka $T$, Kubota $Y$, et al : Ultrasonically guided percutaneous ethanol injection therapy for hepatocellular carcinoma. Am J Gastroenterol 84 : 1400-1407, 1989

6) Ishii, $H$, Okada $S$, Nose $H$, et al : Local recurrence of hepatocellular carcinoma after percutaneous ethanol injection. Cancer 77 : 17921796, 1996

7) Ebara $M$, Ohto $M$, Sugiura $N$, et al: Percutaneous ethanol injection for the treatment of small hepatocelullar carcinoma. J Gastroenterol Hepatol 5:616-626, 1990

8) Livraghi T, Giorgio A, Marin G, et al: Hepatocellular carcinoma and cirrhosis in 746 patients: Long-term results of percutaneous ethanol injection. Radiology $197: 101-108$, 1995

9) Katoh K, Sakai H, Sakamoto S, et al: The effect of percutaneous ethanol injection therapy on small solitary hepatocellular carcinoma is comparable to that of hepatectomy. Am J Gastroenterol 89 : 194-198, 1994

10) Shiina $S$, Tagawa $K$, Unuma $T$, et al: Percutaneous ethanol injection therapy for hepatocellular carcinoma: A histopathologic study. Cancer 68: 1524-1530, 1991

11) Shiina $S$, Tagawa $K$, Niwa $Y$, et al: Percutaneous ethanol injection therapy for hepatocellular carcinoma: Results in 146 patients. Am J Roentgenol $160: 1023-1028$, 1993

12) Cedrone A, Rapaccini GL, Pompili M, et al: Neoplastic seeding complicating percutaneous 
ethanol injection for treatment of hepatocellular carcinoma. Radiology 183 : 787-788, 1992

13) Shimada M, Maeda $T$, Saitoh $A$, et al : Needle track seeding after percutaneous ethanol injection therapy for small hepatocellular carcinoma. J Surg Oncol 58:278-281, 1995

14) Seki $T$, Wakabayashi $M$, Nakagawa $T$, et al : Percutaneous microwave coagulation therapy for patients with small hepatocellular carcinoma. Cancer $85: 1694-1702,1999$

15) Hirata $M$, Nishimura $N$ : Hepatocellular carcinoma recurrence after percutaneous ethanol injection therapy: Comparison of tumors with or without a septum. Jan J Med Ultrasonics $20: 548-554,1993$

16) Seki T, Wakabayashi M, Nakagawa $T$, et al : Ultrasonically guided percutaneous microwave coagulation therapy for small hepatocellular carcinoma. Cancer $74: 817-825,1994$

17) Ohnishi $K$, Nomura F, Ito $S$, et al : Prognosis of small hepatocellular carcinoma (less than $3 \mathrm{~cm}$ ) after percutaneous acetic acid injection: Study of 91 cases. Hepatology $23: 994-1002,1996$

18) Tamai $T$, Seki $T$, Imamura $M$, et al : Development of local necrosis, side-effects and histopathological study after hepatic injection of acetic acid solutions. Hepatol Commun $6: 153$ $-157,1997$

19）関 寿人, 若林正之, 中川泰一他：細小肝癌に対 する経皮的マイクロ波凝固治療 (PMCT).肝・胆・ 脺 $31: 251-254,1995$

20）山中若樹, 岡本英三, 折山毅他：小肝癌の病態 と治療方針. 消外 $18 ： 429-435,1995$

21) Horigome H, Nomura $T$, Saso $K$, et al: Standards for selecting percutaneous ethanol injection therapy or percutaneous microwave coag. ulation therapy for solitary small hepatocellular carcinoma : Consideration of local recurrence. Am J Gastroenterol 94 : 1914-1917, 1999

22）片山和宏, 柄川悟志, 前山晋吾他：横隔膜直下肝 細胞癌に対する診断と治療の新しいアプローチ： 人工胸水法 (Artificial pleural effusion method) による検討. 肝臓 $40 ： 268,1999$

\title{
SERECTION OF TREATMENT FOR SMALL HEPATOCELLULAR CARCINOMA FROM THE VIEWPOINT OF THE HISTOPATHOLOGICAL PROGRESSION
}

\author{
Seiji MORI, Takashi MAEBA, Ken ISHIMURA, \\ Keiichi OKANO, Yukihiko KARASAWA, Fuminori GODA, \\ Hisao WAKABAYASHI, Hisashi USUKI and Hajime MAETA \\ First Department of Surgery, Kagawa Medical University
}

In order to select the best treatment for the patients with small hepatocellular carcinoma (HCC), histopathological progression of the small HCC (less than $3 \mathrm{~cm}$ in diameter and within 3 lesions) was examined on 49 patients ( 56 nodules) who underwent hepatectomy. These 56 nodules were classified by the tumor diameters (less than $15 \mathrm{~mm}, 12$ nodules ; $16-20 \mathrm{~mm}, 20 ; 21-25 \mathrm{~mm}, 16$; and $26-30 \mathrm{~mm}, 8$ ). Since extracapsular progression (extracapsular invasion, intrahepatic metastasis, or invasion to the blood vessels) was noted in only one nodule $(8.3 \%)$ in $\mathrm{HCC}$ of less than $15 \mathrm{~mm}$ in diameter. Percutaneous ethanol injection therapy (PEIT) seemed to be the first choice of the treatment. However, moderately or poorly differentiated HCC, or no formation of HCC capsular was observed in six nodules (50\%), or five nodules (41.7\%), respectively. This results seemed to be a risk factor which might cause the local recurrence after PEIT. In HCC over $16 \mathrm{~mm}$ in diameter, capsular invasion and extracapsular progression within $1 \mathrm{~cm}$ from the tumor edge were observed in high rates (59.1\% and $45.5 \%$, respectively). Moreover, one nodule ( $22 \mathrm{~mm}$ in diameter) in four nodules of resected HCC after PEIT showed the viable cancer cells of intrahepatic metastasis pathologically. In HCC over $16 \mathrm{~mm}$ in diameter, the therapy which insure the local control including the tumor circumference such as hepatectomy or microwave coagulation therapy, should be selected. 